\title{
Polyethylene Nail Brace for Ingrown Toenails Treatment: A Randomized Clinical Trial
}

\author{
Salvador Márquez-Reina ${ }^{1}\left(\mathbb{0}\right.$, Inmaculada Palomo-Toucedo ${ }^{2}$ (), María Reina-Bueno ${ }^{2}{ }^{\circledR}$, \\ José Manuel Castillo-López ${ }^{2}$, Javier Ramos Ortega ${ }^{2}$, César Calvo-Lobo ${ }^{3}{ }^{\circledR}$, \\ Daniel López-López ${ }^{4, *(\mathbb{D})}$ and Gabriel Domínguez-Maldonado ${ }^{2}[\mathbb{C}$
}

1 Nuestra Señora de la Oliva Foot Clinic, Bda. Ntra. Sra. de la Oliva Bq. 24, Bajo B, 41013 Sevilla, Spain; podosalva@hotmail.com

2 Departamento de Podologia, Universidad de Sevilla, Calle Avicena, s/n, 41009 Sevilla, Spain;

ipalomo@us.es (I.P.-T.); mreina1@us.es (M.R.-B.); jmcastillo@us.es (J.M.C.-L.); jrortega@us.es (J.R.O.); gdominguez@us.es (G.D.-M.)

3 School of Nursing, Physiotherapy and Podiatry, Universidad Complutense de Madrid, 28040 Madrid, Spain; cescalvo@ucm.es

4 Research, Health and Podiatry Group, Department of Health Sciences, Faculty of Nursing and Podiatry, Universidade da Coruña, 15403 Ferrol, Spain

* Correspondence: daniellopez@udc.es; Tel.: +34-981-16-70-00 (ext. 3546)

Received: 17 September 2020; Accepted: 22 October 2020; Published: 23 October 2020

\begin{abstract}
Background: Onychocryptosis is one of the most prevailing onychopathies and one of the usual reasons for visiting podiatry clinics. In this research, we aim to evaluate the effectiveness of a procedure of nail reeducation technique via a strip of polyethylene in subjects with stage I or IIa onychocryptosis, in which pathological toenail curves are present. Methods: This research was a randomized clinical trial (ACTRN12615000834550). The sample was made up of 94 cases of stage I or IIa onychocryptosis, according to the Mozena classification. Briefly, 46 cases were treated with the combination of a spicule technique and nail brace with a polyethylene plastic strip, and 48 were only treated with the spicule technique. Results: The combination of the spicule technique and the nail brace technique with a strip of polyethylene had a significantly lower recurrence rate compared to that achieved with just the spicule technique, twelve months after the beginning of the study (N.S. $=0.000$ for $\alpha=0.05$ ). The change in the nail width achieved with the nail brace technique, twelve months after the beginning of the study, was statistically significant (N.S. $=0.000$ for $\alpha=0.05$ ). Conclusions: The recurrence rate of the spicule technique alone was significantly higher than the combined technique of spicule with nail brace. A nail brace with a strip of polyethylene reduces the recurrence rate of onychocryptosis.
\end{abstract}

Keywords: onychocryptosis; nail curves; nail brace; orthonyxia; spicule

\section{Introduction}

Of all the onychopathies described, onychocryptosis is undoubtedly one of the most prevailing conditions and one of the usual reasons for visits to podiatry clinics. It was defined for the first time in 1845 as "a nail which grows towards the inside of the flesh" as a consequence of an excessive curvature, which causes pain and inflammation of the surrounding tissues. It has a prevalence of $20 \%$ of the patients who visit for a foot pathology [1]. In a study carried out with 10,900 podiatry patients, it was indicated that $61 \%$ of them (6754) presented symptomatic nail conditions. There is a predilection for the first toe of the foot and its peroneal edge (with a proportion of 2-5:1) [2], although it can affect any toe and either of the two edges [3,4]. 
In 2002, Mozena [5] classified this pathology into four stages: stage I or inflammatory, stage II or abscess, which is divided into two substages, stage IIa and stage IIb, and stage III. In the initial stages of the onychocryptosis (stages I and IIa), conservative treatments are efficient in reducing painful processes, solving a great number of cases, which is why they are considered first-choice treatments [6].

Nail reeducation techniques can be varied: applying cotton impregnated with alcohol below the nail edges, plugging with gauze, applying plastic cannulas, applying dental floss, acrylic resin nails, metallic nail braces, or plastic nail braces.

In this study, we investigate the effectiveness of a procedure of nail reeducation in subjects with onychocryptosis at stages I or IIa, who present pathological nail curves, using a nail brace technique carried out with a strip of polyethylene (polyethylene orthonyxia) stuck to the nail with cyanoacrylate.

\section{Materials and Methods}

\subsection{Design and Sample}

We have carried out an ongoing, phase IV, blinded parallel-group, randomized clinical trial with an endpoint classification of efficacy study 1:1 allocation ratio conducted at an only-podiatry medical center. No changes were made in the proposed methodology because the original protocol was not altered. Furthermore, the Consolidated Statement for Reporting Trials (CONSORT) statement and checklist were considered. The study factor was the type of treatment, which had two values: one of which was the combination of the spicule technique and the nail brace technique with a strip of polyethylene (experimental group), and the other just the spicule technique (control group). The assignation of each subject to the randomized clinical trial was computer-generated by the statistic software Epidat version 4.2 (Consellería de Sanidade, Xunta de Galicia, España; Organización Panamericana de la salud (OPS-OMS); Universidad CES, Colombia).

\subsection{Subjects}

The sample was made up of 94 cases of mild pincer toenail onychocryptosis at stages I and IIa, according to Mozena's classification [5]. Sixty-four people took part: 17 men and 47 women. Forty-six cases made up the experimental group and 48 cases the control group. The mean age was 54.9 years old for the experimental group and 57.96 years old for the control group.

\subsection{Ethics Considerations}

This randomized clinical trial was approved by the local Experimental and Ethics Committee of the University of Seville, in Seville, Spain, with 20 February 2012 as the date of signing, and it was recorded in the Australian New Zealand Clinical Trials Registry (ACTRN12615000834550). All voluntary patients provided their written consent form before the randomized clinical trial started. Human research ethical standards, according to the Helsinki Declaration, the human rights and biomedicine statements regarding the Convention of the Council of Europe, as well as the human genome and rights considered by the UNESCO Universal Declaration and other appropriate national or institutional organizations, were respected.

\subsection{Sample Size}

$G^{*}$ Power version 3.1.9.7 statistics power tool software was used to analyze and establish the sample size; a $90 \%$ confidence level, with 0.95 power and a 0.05 alpha level, was utilized. Additionally, a $15 \%$ sample loss was also adivsed. This procedure was stipulated based on the experience of previous studies carried out by the authors. Finally, the necessary sample size obtained was thirty cases each for the control and experimental groups, making a total of sixty cases, although more cases were recruited due to the estimated magnitude of data loss. One hundred cases were randomly separated into two groups of fifty cases, in which six cases were discarded from the study due to experimental death; of these, four were from the study group and two from the control group. 


\subsection{Procedures}

Having obtained the patients' informed consent, which fulfilled the inclusion criteria, a complete clinical history was carried out. Next, a straight nail cut was done at the hyponychium level. Later, the width of the nail was measured. Nail hyponychium was taken as a reference to affect the measurement of the nail width, as it is a fixed point of reference in all people. A caliber was used for the measurement. Later, the spicule technique of the nail edge or edges affected by onychocryptosis was carried out. The nail portion that injures the periungual soft tissues, causing onychocryptosis, is called a spicule.

We now describe the technique of cutting the nail spicule [7,8]. After disinfecting the area, the edge of the nail is milled in order to weaken the sheet and facilitate cutting. A first oblique cut is made with a nail clipper and finished with a number 15 scalpel, pointing dorsally. The spicule is cut to the back of the affected area and extracted with the help of fine forceps, ensuring that the end of the cut does not form an angle that could create a harpoon.

This treatment was performed at least once in all the subjects belonging to the study, both in the study group and in the control group. Local cures with povidone-iodine were indicated once a day for a week.

In the experimental group, in addition to the previous treatment, a nail brace was applied to correct the nail layer. The polyethylene nail brace consisted of applying a flat strip of this type of plastic between the free edge and the middle area of the nail, which, being stuck on the nail with cyanoacrylate and having elastic memory toward the horizontality, tends to modify its curvature. The principles of action are based on the tensile forces exercised by the plastic strips, which act directly on the proximity of the nail matrix and will accompany the growth of the nail, affecting traction in its more distal zones.

The nail brace technique, with a plastic strip, is bloodless, painless, and enables carrying out any kind of movement and using any type of footwear; it is easy to apply and of little economic cost [9].

The strips of polyethylene were obtained from $0.5 \mathrm{~mm}$ thick polyethylene sheets. It was necessary to measure the width of the nail strip with a tape measure to adjust the size of the nail brace to the needs of each case (Figure 1). The length of the polyethylene strip was $2 \mathrm{~mm}$ less than the length of the nail from one side to the other, $1 \mathrm{~mm}$ less for each end. The width with which the plastic strip was cut was a third of the measure of the nail from the eponychium to the free edge.

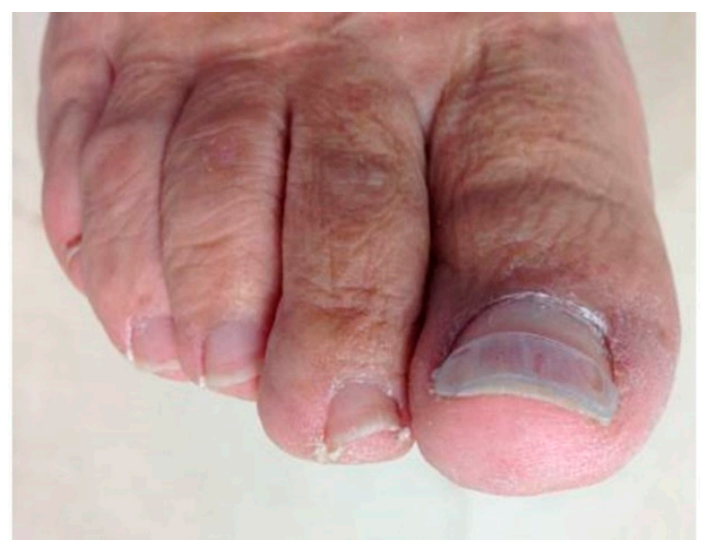

Figure 1. Strip of polyethylene treatment in ingrown toenails.

The growth time of the toenails from the matrix to the free edge can be 12-18 months, depending on the location. The modification of the curvature of the nail from the eponychium to the free edge was observed, measuring the modification of the nail curvature at the level of the hyponychium. We have followed the same treatment time as a similar investigation of nail reeducation with plastic sheet orthonyxia, which was 6 months [9]. All the subjects who made up the experimental group were given a minimum of three nail braces. The first when starting the study, then another after two months, and, lastly, the third after four months. In the event of an accidental detachment, a new strip 
of polyethylene was put into place, and, in this case, the subject undertook to notify us when this happened. We considered the follow-up period to start once the treatment period had ended since the treatment was carried out over 6 months. The follow-up period was another 6 months. This follow-up period is also that of diverse authors consulted in the bibliography [10-15]. All the study subjects were given a check-up appointment every 2 months during a year. At these check-ups, the evolution was confirmed, and the nail width was measured in the study group's subjects after 2, 4, 6, and 12 months (Figures 2-4).

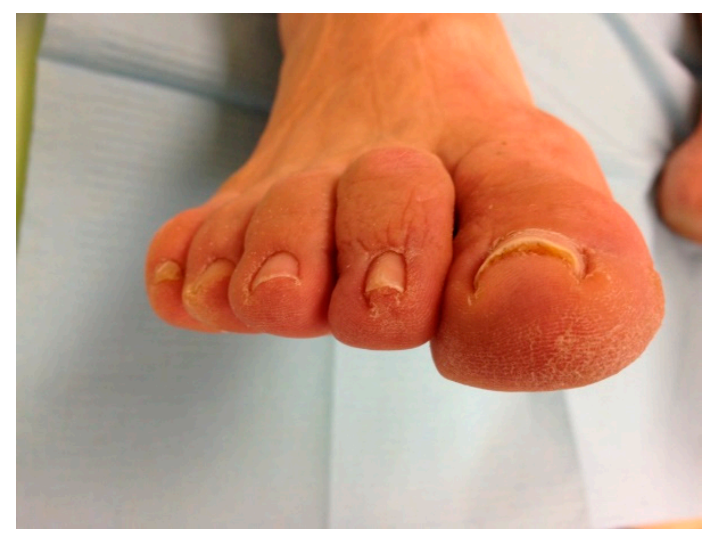

Figure 2. Initial appearance of the 1st toenail.

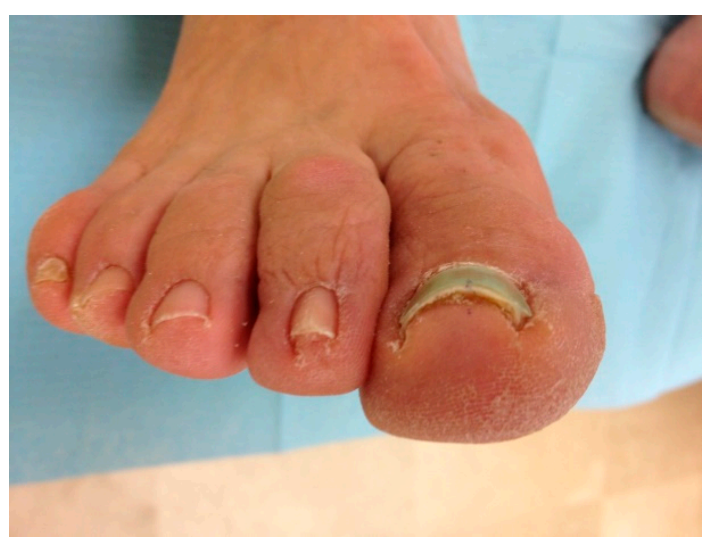

Figure 3. Appearance at 6 months.

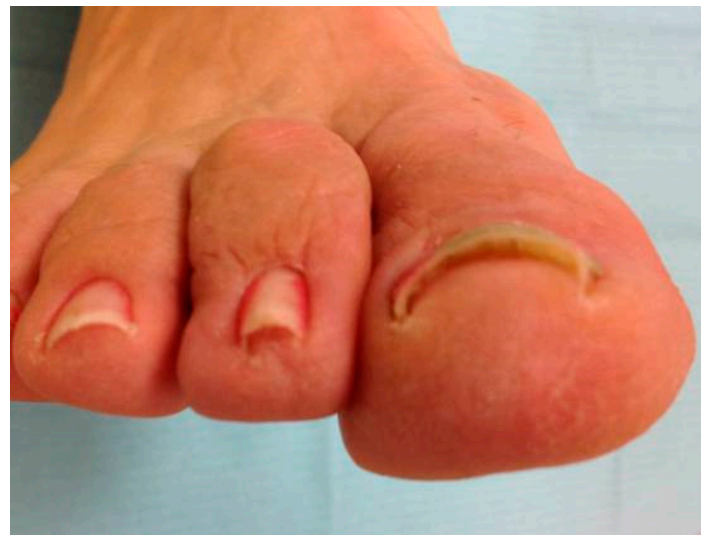

Figure 4. Appearance at 12 months.

At these check-ups, the subjects who made up the control group only had the nail cut done at the level of the hyponychium, without spicule treatment, if they did not present recurrences. 


\subsection{Data Collection and Analysis}

The data were analyzed with the SPSS ${ }^{\circledR}$ computer pack, version 17.0 for Windows ${ }^{\circledR}$ (SPSS Science, Chicago, IL, USA).

The Kolmogorov-Smirnov test was used to determine the normality of certain variables. The Mann-Whitney U-test and the Wilcoxon $t$-test were used.

The Pearson correlation test was employed for the study of measurement reliability.

Its reliability has been assessed, repeating the measurement process with the aim of analyzing the concordance between the different measures. We studied different aspects of reliability: intraobserver concordance and interobserver concordance.

\section{Results}

Table 1 shows the recurrence values during the period of treatment and follow-up, respectively, in the two study groups.

Table 1. Recurrence data of ingrown toenails in both groups.

\begin{tabular}{ccccc}
\hline & \multicolumn{2}{c}{ Treatment Period } & \multicolumn{2}{c}{ Follow-Up Period } \\
\cline { 2 - 5 } & No Recurrence & Recurrence & No Recurrence & Recurrence \\
\hline Experimental Group & $33(71.74 \%)$ & $13(28.26 \%)$ & $36(78.26 \%)$ & $10(21.74 \%)$ \\
\hline Control Group & $2(4.17 \%)$ & $46(95.83 \%)$ & $4(8.33 \%)$ & $44(91.67 \%)$ \\
\hline
\end{tabular}

During the treatment period, in the experimental group, there were only 13 cases with some recurrences. On the other hand, in the control group, almost all subjects had at least one recurrence. Only 10 cases of the experimental group had any recurrence during the follow-up period (Table 1).

Taking into account the follow-up period after treatment, in the group with the nail brace, it was noted that $56.52 \%$ of the sample did not repeat any symptomology during that year. On the other hand, with only the spicule treatment, $95.83 \%$ had to revisit the podiatrist for treatment. This meant that not applying the nail brace after spicule treatment led to 11.22 times more recurrences in the control group than in the study group, beyond even the phase of treatment, taking measures throughout all of a year.

The Mann-Whitney U-test showed significance values of less than 0.001 when compared to the number of recurrences in both groups, both considering and not considering the follow-up period.

With respect to the measuring of the nail width, Table 2 shows the values of nail widths recorded in the study group during the treatment and the follow-up. It can be noted, descriptively, that there was an increase in this width during the period of treatment.

Table 2. Descriptive parameters of the nail width measurements in the experimental group.

\begin{tabular}{cccccc}
\hline & $\begin{array}{c}\text { Initial Nail } \\
\text { Width }\end{array}$ & $\begin{array}{c}\text { Nail Width } \\
\text { after 2 Months }\end{array}$ & $\begin{array}{c}\text { Nail Width } \\
\text { after 4 Months }\end{array}$ & $\begin{array}{c}\text { Nail Width } \\
\text { after 6 Months }\end{array}$ & $\begin{array}{c}\text { Nail Width after } \\
\text { 12 Months }\end{array}$ \\
\hline Mean & $12.86 \pm 2.70$ & $13.88 \pm 2.55$ & $14.41 \pm 2.57$ & $15.01 \pm 2.67$ & $14.03 \pm 2.57$ \\
\hline Minimum & 4.83 & 6.20 & 6.88 & 7.04 & 5.49 \\
\hline Maximum & 16.78 & 17.60 & 17.98 & 18.25 & 17.52 \\
\hline \multicolumn{5}{c}{ All measurements are in millimeters. }
\end{tabular}

The measurements of nail width in all the assessments carried out during the application of the treatment (up to 6 months), as well as the comparison of the nail width 6 months after finishing the treatment (follow-up period), showed significant differences with respect to the initial width $(<0.001)$ using the Wilcoxon test. A progressive increase can be noted in the nail width during the treatment period, which is related to a change in the nail's morphology, reducing its curve. However, 6 months after applying the treatment, this value decreases. That is to say, the nail layer shows a tendency to 
partially recover its initial curve, showing values very similar to those achieved after 2 months of treatment. However, despite this, the percentage of recurrence of pain symptoms did not increase at the end of the follow-up period. We plan to extend the follow-up period in future studies to be able to check if the tendency of the nail over time is to equal the initial width and if there are recurrences of the symptoms.

For the study of the reliability of the measurements, we carried out five measurements of 10 different nails at three different moments-the first measurement after a week and then after two weeks-in such a way that we could verify an index of intrasubject reliability. Likewise, a second examiner did the same measurements to value intersubject reliability. We studied the Pearson correlation index, which showed values of between 0.99 and 1 for all the measurements studied, both for the intraobserver measurements and the interobserver measurements. This guaranteed the reliability of the measurement technique used.

\section{Discussion}

Among the studies that have carried out on nail reeducation techniques with a plastic strip, according to Effendy et al. [16], the effectiveness rate obtained was $100 \%$ during a follow-up that went from 3 to 6 months. However, it has to be taken into account that this was a study done with a sample of 3 cases, and the application time of the treatment was not specified. On the other hand, Di Chiacchio et al. [9], with a sample of 25 cases and 6 months of treatment, established an effectiveness rate of $100 \%$ during a follow-up period that went from 3 to 6 months. In both studies, the follow-up period was not exactly the same as in this study as they indicated that it went from 3 to 6 months, while in this study, it was 6 months in all cases. Additionally, our sample size differed quite a lot from the two previous studies. Nor was the stage of the onychocryptosis of the subjects included in the sample specified.

Studies that have evaluated the effectiveness of other nail brace techniques and nail reeducation techniques are referenced to be able to make comparisons with this study (Table 3).

Most of these studies did not have a research method similar to this study. Many had a fundamentally descriptive aim, showing the results obtained with a specific technique or with various techniques at the same time in the same study; a study group that was compared with a control group was lacking. It was thus difficult to interpret their results. Other publications that were found were based purely on empirical data and, therefore, did not offer scientific data on the results or the recurrence rates.

As to the effectiveness rate of the spicule technique alone, few studies have been published (Table 4). When analyzing the nail width variable, it has been noted that an average difference of $1.8798 \mathrm{~mm}$ was obtained after 6 months and $0.8185 \mathrm{~mm}$ after 12 months. We compared the nail width measurements of the subjects of the study group after 6 months and 12 months and we noted descriptively that there was a decrease of this width, the average decrease being $-1.0613 \mathrm{~mm}$. This is the period in which the subjects did not have the nail brace in place. That is to say, it seems that the nails treated have a certain capacity of memory and tend to curve slightly with the passing of time. 
Table 3. Studies of the effectiveness of other nail brace techniques and nail reeducation techniques.

\begin{tabular}{|c|c|c|c|c|c|}
\hline \multicolumn{6}{|c|}{ Nail Brace Techniques } \\
\hline Studies & Year & $\mathrm{N}^{\circ}$ Cases & Treatment Time & Follow-Up Time & Effectiveness Rate \\
\hline Van Oirschot et al. [17] & 1994 & 85 & Average 9 sessions & - & $76.5 \% *$ \\
\hline Kim and Sim [13] & 2003 & 14 & 1 month & 12 months & $100 \%$ \\
\hline Harrer et al. [11] & 2005 & 21 & - & 6-12 months & $81 \%$ * \\
\hline Erdogan [18] & 2008 & 7 & - & 6 months & $100 \%$ \\
\hline Iribarren and Delgado [19] & 2006 & 10 & - & - & $100 \%$ \\
\hline Cabo and Macián [20] & 2007 & - & 141 days & - & $82 \%$ * \\
\hline Erdogan and Erdogan [21] & 2006 & 21 & $4.1 \pm 2.36$ months & 2 years & $71.4 \%$ * \\
\hline Kruijff et al. [10] & 2008 & 47 & - & 12 months & $82.98 \%$ * \\
\hline Ishibashi et al. [22] & 2008 & 14 & - & 3 months & $100 \%$ \\
\hline Kim and Park [23] & 2009 & 31 & 3 weeks & $13.3 \pm 4.9$ months & $93.55 \%$ \\
\hline Moriue et al. [24] & 2008 & 5 & - & $>6$ months & $100 \%$ \\
\hline Matsumoto et al. [25] & 2010 & 61 & 9.3 months & 10 months & $91.8 \%$ \\
\hline Erdogan [26] & 2011 & 21 & $6-10$ months & - & $100 \%$ \\
\hline Okada and Okada [15] & 2012 & 106 & $\geq 5$ days & $\begin{array}{c}4.6 \text { months (range } 2-12 \\
\text { months) }\end{array}$ & $92.45 \%$ \\
\hline Moon et al. [27] & 2013 & 15 & - & $\begin{array}{l}9 \text { months (range 5-12 } \\
\text { months) }\end{array}$ & $86.67 \%$ \\
\hline Tseng et al. [28] & 2013 & 43 & 2-3 months & 6 months & $95.35 \%$ \\
\hline Kim et al. [29] & 2013 & 21 & 2-3 weeks & $\begin{array}{l}\text { Foreseen: } 12 \text { weeks } \\
\text { Later: } 37.9 \pm 21.3 \text { weeks } \\
\text { (range } 16-84 \text { weeks) }\end{array}$ & $\begin{array}{c}90.5 \% \text { (12 weeks) } \\
57.14 \% \text { (range } 16 \text { to } 84 \text { weeks) }\end{array}$ \\
\hline Park et al. [30] & 2014 & 31 & $\begin{array}{l}\text { From 2-3 weeks or more } \\
\text { (41 days) }\end{array}$ & 161 days & $77.4 \%$ * \\
\hline Guler et al. [31] & 2015 & 74 & $\begin{array}{l}\text { Until cure and correction } \\
\text { nail curve }\end{array}$ & $12.7 \pm 3.9$ months & $91.9 \%$ \\
\hline
\end{tabular}


Table 3. Cont.

\begin{tabular}{|c|c|c|c|c|c|}
\hline \multicolumn{6}{|c|}{ Nail Brace Techniques } \\
\hline Studies & Year & $\mathrm{N}^{\circ}$ Cases & Treatment Time & Follow-Up Time & Effectiveness Rate \\
\hline Arik et al. [32] & 2016 & 41 & $4-6$ weeks & $\begin{array}{l}\text { Range } 6-12 \text { months }(8.6 \pm \\
2.1 \text { months })\end{array}$ & $80.5 \%$ * \\
\hline This study & & 46 & 6 months & 6 months & $78.26 \%$ * \\
\hline \multicolumn{6}{|c|}{ Nail reeducation techniques } \\
\hline Lloyd-Davies and Brill [1] & 1963 & 100 & - & 2 years & $60 \% *$ \\
\hline Wallace et al. [12] & 1979 & $\begin{array}{c}\text { Study } 1 \\
\text { (retrospective): } \\
25 . \\
\text { Study } 2 \\
\text { (prospective): } \\
36\end{array}$ & 6 weeks10-12 weeks & 6 months & $\begin{array}{l}52 \% \text { (retrospective study) } \\
56 \% \text { (rrospective study) }\end{array}$ \\
\hline Cameron [33] & 1981 & 100 & 3.5-4 months & 6 months & $61 \% *$ \\
\hline Senapati [34] & 1986 & 25 & - & $\begin{array}{c}2-56 \text { weeks (of } 23.7 \pm 14.3 \\
\text { weeks) }\end{array}$ & $79 \%$ * \\
\hline Connolly and Fitzgerald [35] & 1988 & 61 & - & 2.5 years & $72 \%$ * \\
\hline Reijnen y Goris [36] & 1989 & $\begin{array}{c}\text { Stage I: } 20 \\
\text { Stage II: } 47 \\
\text { Stage III: } 52 \\
\text { Total: } 119\end{array}$ & $\begin{array}{c}\text { From } 2 \text { weeks until pain } \\
\text { disappeared }\end{array}$ & 2 years & $\begin{array}{c}96 \%(\text { stage I and II) } \\
38 \% \text { (stage III) }\end{array}$ \\
\hline Ilfeld [37] & 1991 & 43 & - & - & $97.68 \%$ * \\
\hline Salasche et al. [38] & 1998 & 62 & - & 2 years & $100 \%$ * \\
\hline Lazar et al. [39] & 1999 & 20 & 3-9 weeks & - & $95 \% *$ \\
\hline You et al. [40] & 2001 & 27 & - & 6 months & $37 \%$ * \\
\hline Gupta et al. [41] & 2001 & 39 & - & 6 months & $79.5 \%$ * \\
\hline Abby et al. [42] & 2002 & 28 & - & 4 months & $71.4 \%$ * \\
\hline Kim et al. [43] & 2003 & $\begin{array}{l}\text { Group 1: } 28 \\
\text { Group 2: } 29\end{array}$ & $\begin{array}{l}\text { Group 1: } 3 \text { days } \\
\text { Group 2: } 2 \text { weeks }\end{array}$ & 1 year & $\begin{array}{l}92.8 \% \text { (treatment of } 3 \text { days) * } \\
89.7 \% \text { (treatment of } 2 \text { weeks) }\end{array}$ \\
\hline Ozawa et al. [44] & 2005 & 9 & 2 weeks & $\begin{array}{c}\text { 6-37 months (average } 17.7 \\
\text { months) }\end{array}$ & $89.89 \%$ * \\
\hline
\end{tabular}


Table 3. Cont.

\begin{tabular}{|c|c|c|c|c|c|}
\hline \multicolumn{6}{|c|}{ Nail Brace Techniques } \\
\hline Studies & Year & $\mathrm{N}^{\circ}$ Cases & Treatment Time & Follow-Up Time & Effectiveness Rate \\
\hline Nazari [45] & 2006 & 32 & $7-15$ days & 6 months & $93.75 \%$ * \\
\hline Lee et al. [46] & 2011 & 30 & - & Average 8.42 months & $60 \% *$ \\
\hline Doğan et al. [47] & 2013 & 16 & 2 weeks & 6 months & $100 \% *$ \\
\hline Ceren et al. [48] & 2013 & 57 & 15 days & 6 months & $87.8 \%$ * \\
\hline AlGhamdi and Khurram [49] & 2014 & 23 & 1 months & 6 months & $80 \%$ * \\
\hline Taheri et al. [50] & 2014 & 11 & $\geq 4$ weeks & 5 months & $81.82 \%$ * \\
\hline Gutiérrez-Mendoza et al. [51] & 2015 & 10 & 2 months & 2 months & $80 \% *$ \\
\hline This study & & 46 & 6 months & 6 months & $78.26 \%$ * \\
\hline
\end{tabular}

Note: * The results of this study and those that are close to it. 
Table 4. Studies of spicule technique effectiveness and the nail curve correction with nail reeducation techniques.

\begin{tabular}{|c|c|c|c|c|c|}
\hline \multicolumn{6}{|c|}{ Spicule Technique Effectiveness } \\
\hline Studies & Year & $\mathrm{N}^{\circ}$ Cases & Treatment Time & Follow-Up Time & Effectiveness Rate \\
\hline Maeda et al. [52] & 1990 & 22 & $\begin{array}{l}15.9 \text { months (range } \\
3-48 \text { months) }\end{array}$ & 6 months & $22.73 \%$ \\
\hline Stoduto and Palomo [53] & 2014 & 32 & - & - & $90.62 \%$ \\
\hline This study & & 48 & 6 months & 6 months & $8.33 \%$ \\
\hline \multicolumn{6}{|c|}{ Nail Curve Correction Studies } \\
\hline Studies & Year & $\mathbf{N}^{\circ}$ Cases & $\begin{array}{l}\text { Nail Curve } \\
\text { Correction }\end{array}$ & \multicolumn{2}{|c|}{ Observations } \\
\hline Di Chiacchio et al. [9] & 2006 & 25 & $3.04 \mathrm{~mm}$ & \multicolumn{2}{|c|}{$\begin{array}{l}\text { Index of nail width increases and index of } \\
\text { height decreases after treatment }\end{array}$} \\
\hline Lee et al. [46] & 2011 & 30 & - & \multicolumn{2}{|c|}{-} \\
\hline Kim et al. [29] & 2013 & 21 & - & \multicolumn{2}{|c|}{$\begin{array}{c}\text { Transversal nail width decreases and } \\
\text { width index is maintained after treatment. }\end{array}$} \\
\hline This study & & 46 & $1.8798 \mathrm{~mm}$ & \multicolumn{2}{|c|}{$\begin{array}{l}\text { Nail width mean decreases in the } \\
\text { follow-up period (without orthonyxia). } \\
\text { Tendency to increase nail curve. }\end{array}$} \\
\hline
\end{tabular}

Within the studies that have analyzed changes in the nail width (Table 4), in the study carried out by Di Chiacchio et al. [9], they found an average difference of a change in nail width of $3.04 \mathrm{~mm}$ at the end of the 6-month treatment period. This was the same time carried out in this study, although they used a greater number of applications of orthonyxia in each subject, specifically six, one for each month treated. In this clinical trial, we applied a nail brace every two months. That is to say, a total of three orthonyxia unless there was an accidental detachment, in which case a new nail brace was put into place. They were also nail braces of different plastics, using the so-called "Sistema clip" of Luga Suministros Médicos S.L. They did not refer to the average nail width that the subjects had at the end of the follow-up period, data that we did record in this study, which is why it has not been possible to make comparisons. Nor did they have a control group.

As was indicated in the study of Di Chiacchio et al. [9], in this clinical trial, we have noted that the greatest average of correction of nail curves took place in the first 2 months of treatment; that is, the average nail correction was significantly higher in the interval of time between the beginning of the study and after 2 months.

Finally, there are some limitations in this clinical trial that have to be mentioned; these are related to (1) restricted sample size, (2) brief follow-up duration, and (3) not being a multicenter study.

\section{Conclusions}

The recurrence rate of the spicule technique alone is significantly higher than the combined technique of spicule with a nail brace. A nail brace with a strip of polyethylene reduces the recurrence rate of onychocryptosis.

Author Contributions: All authors: concept, design, analyses, interpretation of data, drafting of manuscript or revising it critically for important intellectual content. All authors have read and agreed to the published version of the manuscript.

Funding: This research received no external funding.

Conflicts of Interest: The authors declare no conflict of interest. 


\section{References}

1. Lloyd-Davies, R.W.; Brill, G.C. The aetiology and out-patient management of ingrowing toe-nails. Br. J. Surg. 1963, 50, 592-597. [CrossRef]

2. Langford, D.T.; Burke, C.; Robertson, K. Risk factors in onychocryptosis. Br. J. Surg. 1989, 76, 45-48. [CrossRef] [PubMed]

3. DeLauro, N.M.; DeLauro, T.M. Onychocryptosis. Clin. Podiatr. Med. Surg. 2004, 21, 617-630. [CrossRef] [PubMed]

4. Martínez-Nova, A.; Sánchez-Rodríguez, R.; Alonso-Peña, D. A new onychocryptosis classification and treatment plan. J. Am. Podiatr. Med. Assoc. 2007, 97, 389-393. [CrossRef]

5. Mozena, J.D. The Mozena Classification System and treatment algorithm for ingrown hallux nails. J. Am. Podiatr. Med. Assoc. 2002, 92, 131-135. [CrossRef]

6. Woo, S.-H.; Kim, I.-H. Surgical pearl: Nail edge separation with dental floss for ingrown toenails. J. Am. Acad. Dermatol. 2004, 50, 939-940. [CrossRef]

7. Hidalgo, S. Clasificación de las patologías ungueales Estadística de la clínica podológica de la UB. Rev. Esp. Podol. 1999, 10, 349-408.

8. Rodríguez, E. Tratamiento de la onicocriptosis con formación de mamelon carnoso y/o fibrosado. Rev. Esp. Podol. 1992, 3, 71-75.

9. Di Chiacchio, N.; Kadunc, B.V.; Trindade de Almeida, A.R.; Madeira, C.L. Treatment of transverse overcurvature of the nail with a plastic device: Measurement of response. J. Am. Acad. Dermatol. 2006, 55, 1081-1084. [CrossRef]

10. Kruijff, S.; van Det, R.J.; van der Meer, G.T.; van den Berg, I.C.M.A.E.; van der Palen, J.; Geelkerken, R.H. Partial Matrix Excision or Orthonyxia for Ingrowing Toenails. J. Am. Coll. Surg. 2008, 206, 148-153. [CrossRef]

11. Harrer, J.; Schöffl, V.; Hohenberger, W.; Schneider, I. Treatment of ingrown toenails using a new conservative method: A prospective study comparing brace treatment with Emmert's procedure. J. Am. Podiatr. Med. Assoc. 2005, 95, 542-549. [CrossRef] [PubMed]

12. Wallace, W.A.; Milne, D.D.; Andrew, T. Gutter treatment for ingrowing toenails. Br. Med. J. 1979, 2, $168-171$. [CrossRef] [PubMed]

13. Kim, K.-D.; Sim, W.-Y. Surgical pearl: Nail plate separation and splint fixation-A new noninvasive treatment for pincer nails. J. Am. Acad. Dermatol. 2003, 48, 791-792. [CrossRef] [PubMed]

14. Márquez, S.; Castro, A.; Pérez, A.; Bejínez, M.A.; Coheña, M. Tratamiento de la onicocriptosis mediante ortonixia con lámina plástica de polietileno. Podol. Clínia 2011, 12, 104-111.

15. Okada, K.; Okada, E. Novel treatment using thioglycolic acid for pincer nails. J. Dermatol. 2012, 39, 996-999. [CrossRef] [PubMed]

16. Effendy, I.; Ossowski, B.; Happle, R. Pincer nail. Conservative correction by attachment of a plastic brace. Hautarzt 1993, 44, 800-802.

17. Van Oirschot, H.; De Heus, M.; Van Mameren, H. Behandlung von eingewachsenen zehennägeln: Effektivität der orthonyxie im vergleich zu chirurgischen maßnahmen. Der Fuss 1994, 45, 40-44.

18. Erdogan, F.G.; Erdogan, G. Long-Term Results of Nail Brace Application in Diabetic Patients with Ingrown Nails. Dermatol. Surg. 2008, 34, 84-87. [CrossRef]

19. Iribarren, C.; Delgado, A. Técnica MLU. Técnica modificadora de la morfología de la lámina ungueal. Revistapodología 2006, 9, 14-16.

20. Cabo, J.; Macián, C. Tratamiento de la onicocriptosis mediante ortonixia. Podol. Clínica 2007, 8, $164-171$.

21. Erdogan, F.G. A simple, pain-free treatment for ingrown toenails complicated with granulation tissue. Dermatol. Surg. 2006, 32, 1388-1390. [CrossRef] [PubMed]

22. Ishibashi, M.; Tabata, N.; Suetake, T.; Omori, T.; Sutou, Y.; Kainuma, R.; Yamauchi, K.; Ishida, K. A simple method to treat an ingrowing toenail with a shape-memory alloy device. J. Dermatol. Treat. 2008, 19, $291-292$. [CrossRef]

23. Kim, J.-Y.; Park, J.S. Treatment of Symptomatic Incurved Toenail with A New Device. Foot Ankle Int. 2009, 30, 1083-1087. [CrossRef] [PubMed] 
24. Moriue, T.; Yoneda, K.; Moriue, J.; Matsuoka, Y.; Nakai, K.; Yokoi, I.; Nibu, N.; Miyamoto, I.; Kubota, Y. A simple therapeutic strategy with super elastic wire for ingrown toenails. Dermatol. Surg. 2008, 34, 1729-1732. [CrossRef]

25. Matsumoto, K.; Hashimoto, I.; Nakanishi, H.; Kubo, Y.; Murao, K.; Arase, S. Resin splint as a new conservative treatment for ingrown toenails. J. Med. Investig. 2010, 57, 321-325. [CrossRef]

26. Erdogan, F.G. A Quantitative Method for Measuring Forces Applied by Nail Braces. J. Am. Podiatr. Med. Assoc. 2011, 101, 247-251. [CrossRef]

27. Moon, S.H.; Shin, M.K.; Haw, C.R. Clinical study of efficacy of super elastic wire for ingrown nails of great toe. Korean J. Dermatol. 2013, 51, 94-101.

28. Tseng, J.T.-P.; Ho, W.-T.; Hsu, C.-H.; Lin, M.-H.; Li, C.-N.; Lee, W.-R. A Simple Therapeutic Approach to Pincer Nail Deformity Using a Memory Alloy: Measurement of Response. Dermatol. Surg. 2013, 39, 398-405. [CrossRef] [PubMed]

29. Kim, J.Y.; Park, S.Y.; Jin, S.P.; Yoon, H.S.; Cho, S.; Park, H.S. Quick and easy correction of a symptomatic pincer nail using a shape memory alloy device. Dermatol. Surg. 2013, 39, 1520-1526. [CrossRef]

30. Park, S.-W.; Park, J.-H.; Lee, J.-H.; Lee, D.-Y.; Lee, J.-H.; Yang, J.-M. Treatment of ingrown nail with a special device composed of shape-memory alloy. J. Dermatol. 2014, 41, 292-295. [CrossRef]

31. Guler, O.; Tuna, H.; Mahirogullari, M.; Erdil, M.; Mutlu, S.; Isyar, M. Nail Braces as an Alternative Treatment for Ingrown Toenails: Results From a Comparison With the Winograd Technique. J. Foot Ankle Surg. 2015, 54, 620-624. [CrossRef]

32. Arik, H.O.; Arican, M.; Gunes, V.; Kose, O. Treatment of Ingrown Toenail with a Shape Memory Alloy Device. J. Am. Podiatr. Med. Assoc. 2016, 106, 252-256. [CrossRef]

33. Cameron, P.F. Ingrowing toenails: An evaluation of two treatments. Br. Med. J. (Clin. Res. Ed.) 1981, 283, 821-822. [CrossRef] [PubMed]

34. Senapati, A. Conservative Outpatient Management of Ingrowing Toenails. J. R. Soc. Med. 1986, 79, 339-340. [CrossRef] [PubMed]

35. Connolly, B.; Fitzgerald, R.J. Pledgets in ingrowing toenails. Arch. Dis. Child. 1988, 63, 71-72. [CrossRef] [PubMed]

36. Reijnen, J.A.; Goris, R.J. Conservative treatment of ingrowing toenails. Br. J. Surg. 1989, 76, $955-957$. [CrossRef] [PubMed]

37. Ilfeld, F.W. Ingrown toenail treated with cotton collodion insert. Foot Ankle 1991, 11, 312-313. [CrossRef]

38. Salasche, S.J.; Schulte, K.W.; Neumann, N.J.; Ruzicka, T. Surgical Pearl: Nail splinting by flexible tube-A new noninvasive treatment for ingrown toenails. J. Am. Acad. Dermatol. 1998, 39, 629-630. [CrossRef]

39. Lazar, L.; Erez, I.; Katz, S. A conservative treatment for ingrown toenails in children. Pediatr. Surg. Int. 1999, 15, 121-122. [CrossRef]

40. You, M.Y.; Chong, J.H.; Kim, H.U.; Ihm, C.W. Clinical features of 27 cases of ingrowing toenails and treatment with flexible plastic tube insertion. Korean J. Dermatol. 2001, 39, 782-788.

41. Gupta, S.; Sahoo, B.; Kumar, B. Treating Ingrown Toenails by Nail Splinting with a Flexible Tube: An Indian Experience. J. Dermatol. 2001, 28, 485-489. [CrossRef] [PubMed]

42. Abby, N.S.; Roni, P.; Amnon, B.; Yan, P. Modified Sleeve Method Treatment of Ingrown Toenail. Dermatol. Surg. 2002, 28, 852-855. [CrossRef] [PubMed]

43. Kim, Y.-J.; Ko, J.-H.; Choi, K.-C.; Lee, C.-G.; Lim, K.-J. Nail-splinting technique for ingrown nails: The therapeutic effects and the proper removal time of the splint. Dermatol. Surg. 2003, 29, 745-748. [CrossRef] [PubMed]

44. Ozawa, T.; Yabe, T.; Ohashi, N.; Harada, T.; Muraoka, M.; Ishii, M. A splint for pincer nail surgery: A convenient splinting device made of an aspiration tube. Dermatol. Surg. 2005, 31, 94-98. [CrossRef]

45. Nazari, S. A simple and practical method in treatment of ingrown nails: Splinting by flexible tube. J. Eur. Acad. Dermatol. Venereol. 2006, 20, 1302-1306. [CrossRef]

46. Lee, J.I.; Lee, Y.B.; Oh, S.T.; Park, H.J.; Cho, B.K. A clinical study of 35 cases of pincer nails. Ann. Dermatol. 2011, 23, 417-423. [CrossRef]

47. Doğan, F.; Altıparmak, M.; Eskitaşçıŏ̆lu, T.; Özyazgan, İ. A conservative treatment of ingrown toenails: Splinting technique with cyanoacrylate. Eur. J. Plast. Surg. 2013, 36, 715-718. [CrossRef]

48. Ceren, E.; Gokdemir, G.; Arikan, Y.; Purisa, S. Comparison of Phenol Matricectomy and Nail-Splinting With a Flexible Tube for the Treatment of Ingrown Toenails. Dermatol. Surg. 2013, 39, 1264-1269. [CrossRef] 
49. AlGhamdi, K.M.; Khurram, H. Nail tube splinting method versus lateral nail avulsion with phenol matricectomy: A prospective randomized comparative clinical trial for ingrown toenail treatment. Dermatol. Surg. 2014, 40, 1214-1220. [CrossRef]

50. Taheri, A.; Mansoori, P.; Alinia, H.; Lewallen, R.; Feldman, S.R. A Conservative Method to Gutter Splint Ingrown Toenails. JAMA Dermatol. 2014, 150, 1359. [CrossRef]

51. Gutiérrez-Mendoza, D.; De Anda Juárez, M.; Ávalos, V.F.; Martínez, G.R.; Domínguez-Cherit, J. “Cotton Nail Cast": A simple solution for mild and painful lateral and distal nail embedding. Dermatol. Surg. 2015, 41, 411-414. [CrossRef] [PubMed]

52. Maeda, N.; Mizuno, N.; Ichikawa, K. Nail abrasion: A new treatment for ingrown toe-nails. J. Dermatol. 1990, 17, 746-749. [CrossRef] [PubMed]

53. Stoduto, M.; Palomo, P. Onicocriptosis en pediatría: Estudio clínico del tratamiento conservador. Rev. Int. Cienc. Podol. 2014, 8, 83-89.

Publisher's Note: MDPI stays neutral with regard to jurisdictional claims in published maps and institutional affiliations.

(C) 2020 by the authors. Licensee MDPI, Basel, Switzerland. This article is an open access article distributed under the terms and conditions of the Creative Commons Attribution (CC BY) license (http://creativecommons.org/licenses/by/4.0/). 